\title{
OPERATIONAL STRATEGY OF SMES IN BUSINESS COMPETITION THROUGH ENVIRONMENT BASED PRODUCTS / SERVICES IN SOUTH MERUYA - WEST JAKARTA
}

\author{
Agustinus Hariadi and Lenny Christina Nawangsari \\ Universitas Mercu Buana Jakarta, Indonesia.
}

\begin{abstract}
This community service is carried out to encourage the community to be creative and independent with entrepreneurs. Activities can be carried out by partnering, building partnerships will make it easier and more excited. The community of South Meruya village has partnered with PKK and RPTRA Menara, also to help one of the DKI Jakarta government programs. Residents have carried out production activities, if there is a desire or order, for that the scale of production and marketing needs to be increased. These community activities can be expanded to reach products and services that begin with environmental problems that require involvement in conservation as well as having economic potential. It is expected that the community understands the importance of environmental sustainability as an economic resource that can be a source of income for the community. SMEs need to expand business alternatives while simultaneously becoming agents of pollution prevention and improving the quality of life together through a clean environment. The real pressure of pollution and environmental awareness issues has opened up new products that can be marketed. SME business people consider environmental aspects because their awareness of environmentally conscious consumers has increased. After the training and assistance of the SMEs South Meruya community together with PKK will better understood the potential and strategies of a sustainable environment-based business.
\end{abstract}

Keywords: Production Strategies, SMEs, Environment

\section{INTRODUCTION}

The population of Indonesia currently reaches approximately 255 million, on the one hand the amount of money and the poor increases each year as the population grows, on the other hand the number of 'entrepreneurs' is only about $1.65 \%$ (data on the Ministry of Cooperatives and SME ministries, 2015). Ideally the number of entrepreneurs is at least $2 \%$ of the population of a country, such as the number of entrepreneurs in the United States reaching $12 \%$ of the total population, Singapore 7\%, China and Japan also around 10\%; Malaysia 5\% and Thailand 4\%. Thus Indonesia still lacks a minimum of $0.35 \%$ of the population from the minimum standard. Empirical studies show that it is only through the hands of entrepreneurs that 'entrepreneurs / entrepreneurs' will create 'jobs'; they become 'the driving force of the economy' and in their hands economic growth will advance which will ultimately contribute to savings. Terms and Conditions Required to Increase Entrepreneurship Procurement for the Estimated Community New Entrepreneurs, For New Entrepreneurs, and for the community as a medium of cadre of prospective entrepreneurs in Indonesia.

The effort to create entrepreneurial cadres is influenced by many factors including:

a. entrepreneurial character, the entrepreneurial character of a person is initially a heredity of someone who was born from birth (innate nature), but in its development can be changed by experience and environment

b. the family environment is very supportive, especially the family environment that is involved in the business world, this will provide a special experience for someone;

c. social environment, association in the business environment will strengthen to focus on achieving the entrepreneurial regeneration process can be realized.

d. various formal and non-formal entrepreneurship debriefing, briefing both in formal education or short entrepreneurship courses will strengthen their entrepreneurial competence.

f. high commitment, high commitment to pursue entrepreneurship will expedite the process of being an entrepreneur who is able to compete in the business world.

g. and other factors that can influence the formation of entrepreneurs in Indonesia 
Some of the factors that determine the formation of entrepreneurs include the entrepreneurial character a person has, entrepreneurial competence and entrepreneurial commitment that need to be the focus of coaching. Forming and fostering entrepreneurial character is very necessary in order to form and grow entrepreneurs. The nature of a person to be able to be an entrepreneur or not reflected in: a) the nature of a strong desire to stand alone; b) the nature of risk taking; c) the nature of wanting to learn from experience; d) ready to face competition; e) the nature of hard work; f) high self-esteem, g) high-achieving, creative, innovative etc.

Entrepreneurial competence obtained either formally or through non-formal learning such as: internship experience, short courses on business are factors that can support the entrepreneurial traits that have been promoted from birth, and these will help develop entrepreneurs. It is expected that if someone has a strong entrepreneurial character and is supported by adequate entrepreneurial competence, it will increase commitment (attachment) with entrepreneurship, so that this person will continue to improve his career builder to become an entrepreneur.

Entrepreneurial commitment is the attitude or commitment of someone to stay focused and consistent in the field of entrepreneurship that will be occupied in accordance with the competencies and provision of entrepreneurship obtained.

\subsection{Focus on Community Service}

The focus of this service is the Communities in South Meruya, West Jakarta, especially those who have businessess

\subsection{Identification of problems}

1. Based on the results of observations and interviews in the South Meruya village that some business owners do not yet have the knowledge and awareness of environmental-based products and business development strategies. Products from recycled materials and materials that do not pollute the environment and market responses to this type of product / service.

2. The owners of handicraft and food businesses in South Meruya Village have not emphasized the function and benefits of environmental preservation of products / services developed such as packaging used as bag products. This increases the interest of potential customers to buy or consume the services offered so that it impacts on a stable amount of sales each day.

3. The orientation of the business owner is still very local, not yet having the competence and commitment to further develop his business.

\subsection{Purpose of Activity}

Building entrepreneurial competencies and commitments:

a. Regarding understanding of the business / business.

b. Regarding material about Environmental issues and business opportunities.

c. Build awareness of the need to preserve the environment

\subsection{Benefits of Activities}

Community service activities are expected to be useful related:

a. Increased knowledge and insight about the business / business.

b. Increased understanding of environmental conservation and economic aspects.

c. Increased awareness of the need to minimize the impact of each product produced.

d. Commitment to having a sustainable business with environment-based products.

\section{LITERATURE REVIEW}

\section{Operations Management}

Operational Management is a series of activities that produce value in the form of goods and services by converting inputs into outputs (Jay Heizer \& Barry Rnder; 2009)

In running a business it should be planned carefully related to:

- Design of goods and services

- Process design and capacity

- Location selection

- Layout design

- Human resources and job design

- Quality of goods 


\section{METHOD}

The method of implementing the activity to solve the problem of the target audience of PKK ladies, business actors, prospective business actors, and community leaders related to UKM Meruya Selatan West Jakarta's business activities as follows:

1. Lecture, discussion, and question and answer

This method was chosen to convey important concepts to be understood and mastered by P2M participants. The use of this method with the consideration that the lecture method combined with audio and video can provide relatively much material in a compact, fast and easy. The material provided in the form of business knowledge, production, environmental issues, environment-based business and production management. It is expected that the delivery of material provides additional insight, understanding, awareness, and motivation to have a quality business and business sustainability.

2. Questionnaire

This method is used to find out differences in understanding before being given understanding material through lectures, discussions, and questions and answers

3. Monitoring and evaluation.

This method was chosen to monitor the extent of the development of understanding and awareness of participants in managing and developing SMEs in a sustainable and environmentally based product. Guiding Quality Control for SME Products in South Meruya - West Jakarta

\section{RESULT AND DISCUSSION}

\subsection{Field survey}

The initial stage of the training and training process is carried out through focus group discussions (FGD) with Village Office Officials, Chairpersons and Members of the PKK, asking South Meruya Village SMEs, conducted at the South Meruya village office, by seeking information on various creativeness of making bag creations from coffee, flower packs from plastic material like picture 1. Additional information is needed from the village office and PKK who have creativity products in South Meruya.
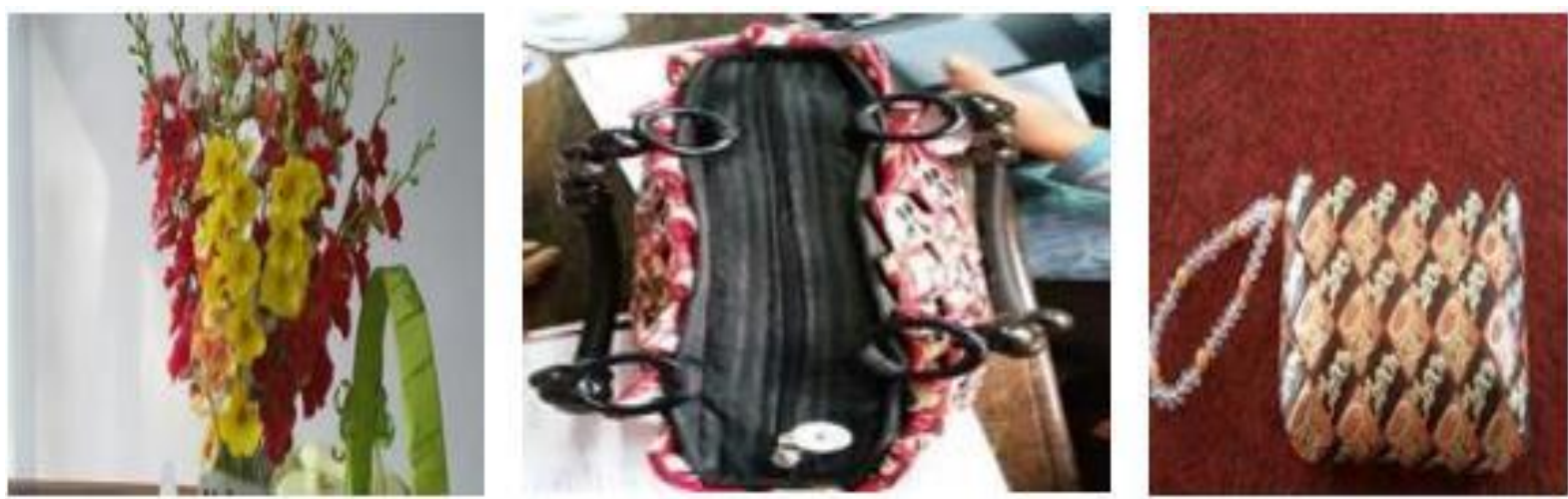

Picture 1: Creation of PKK members

\subsection{Implementation}

The results of community service are described in attendance of participants, participation and seriousness of participants and evaluation of socialization.

1. Attendance of participants

The targets involved in this activity are PKK members, SME business actors and community leaders who are associated with SMEs in South Meruya Village. In the implementation of the activity the number of participants who attended was 25 people exactly as invited. Invitations were given to 25 representatives of management and PKK members in South Meruya village through the village secretary.

2. Participation of participants

Participation and seriousness of the participants can be said to be good. This can be seen from the seriousness of the participants in participating in activities from the event to the end of the activity, followed by lunch together. Participants are very active in discussions and questions and answers that show high curiosity. Communication is conducted in two directions between the participants and the speaker / speaker

The following will be evaluated on the participant profile related to the business operationalization of PKK members in South Meruya village to maintain business sustainability. 


\subsection{Participant Profile}

Profile of respondents below, can be seen in Table 1 - Table 4:

1. Age.

2. Education

3. Status in PKK

4. Business Ownership

Tabel 1. Age of Respondent

\begin{tabular}{|lc|c|c|c|}
\hline & & Frequency & Per cent & $\begin{array}{c}\text { Cumulative } \\
\text { Per cent }\end{array}$ \\
\hline Valid & & & & \\
& $21-30$ year & 3 & 12,00 & 12,00 \\
& $31-40$ year & 6 & 24,00 & 36,00 \\
$41-50$ year & 10 & 40,00 & 76,00 \\
& $51-60$ year & 4 & 16,00 & 92,00 \\
& $>$ 60 year & 2 & 8,00 & 100 \\
Totally & & 25 & 100 & \\
\hline
\end{tabular}

Tabel 2. Education of Respondents

\begin{tabular}{|c|c|c|c|}
\hline & Frequency & Per cent & $\begin{array}{c}\text { Cumulative } \\
\text { Per cent }\end{array}$ \\
\hline Valid & & & \\
\hline Junior school & 1 & 4,00 & 4,00 \\
\hline High Scool & 15 & 60,00 & 64,00 \\
\hline Diploma & 6 & 24,00 & 88,00 \\
\hline Bachelor & 3 & 12,00 & 100 \\
\hline Totally & 25 & 100 & \\
\hline
\end{tabular}

Tabel 3. Posisition of Respondent in PKK Management

\begin{tabular}{|c|c|c|c|}
\hline (1) & Frequency & Per cent & $\begin{array}{c}\text { Cumulative } \\
\text { Per cent }\end{array}$ \\
\hline Valid & & & \\
\hline member & 8 & 32,00 & 32,00 \\
\hline management & 9 & 36,00 & 68,00 \\
\hline others & 8 & 32,00 & 100 \\
\hline Total & 25 & 100 & \\
\hline
\end{tabular}

Tabel 4. Other Activities/ Business Ownership

\begin{tabular}{|r|c|c|c|}
\hline & Frequency & Per cent & $\begin{array}{c}\text { Cumulative } \\
\text { Per cent }\end{array}$ \\
\hline Valid & 8 & 32,00 & 32,00 \\
Have a business & 17 & 68,00 & 100 \\
Candidate have a \\
business
\end{tabular}

\subsection{Discussion of Environmental Based Product}

The material presented states that the environment is a resource that encompasses economic and social aspects. Economic activities should be carried out within the framework of the availability of environmental resources. Exploitation of raw materials that exceed the availability of nature causes stagnation in the economic element itself. The emergence of remaining business processes that exceed the carrying capacity of the environment also 
results in reduced economic and social potential. The involvement of the environment as a foundation is inevitable.

The environment is a place where people look for food, social, economic, political and cultural activities take place; a vehicle for the continuation of life and habitat for various living things. Environmental damage can originate from natural events such as volcanic eruptions, earth quakes, and typhoons and human factors such as pollution (air, water, soil and noise), floods and landslides. Illustration of environmental damage due to human factors is shown in the form of rivers containing chemicals so that the fish die, the air is filled with chemical compounds from factory chimneys, piles of garbage from household waste. Landslides that change the color of nature and also death when events hit humans who live in the landslide site.

Activities that damage the environment are found such as uncontrolled logging, poaching, mangrove destruction, swamp landfill, waste disposal in any place, illegal buildings in the watershed. This activity is countered with positive efforts such as preservation of land, preservation of air, preservation of the sea and beaches, and preservation of flora and fauna. Efforts to preserve the land can be done by promoting activities, planting trees or reforesting (reforestation) of the land that was previously deforested. For hilly or mountainous areas whose sloping ground position needs to be built terraces or swales, so that it can inhibit the flow of rain water.

To keep the air clean and healthy, among others: Promote the planting of trees or ornamental plants; Strive to reduce emissions or exhaust gas from combustion, both forest fires and engine combustion and reduce or even avoid the use of chemical gases that can damage the ozone layer in the atmosphere. Efforts to conserve forests: Reforestation or replanting of deforested forests; Prohibit arbitrary deforestation; Implement a selective cutting system in felling trees; Implement a cutting-planting system in forest logging activities and impose severe sanctions on those who violate the provisions on forest management.

Efforts to preserve the sea and the coast can be done by: Reclaiming the beach by replanting mangroves in the area around the coast; Prohibiting the taking of coral reefs around the coast or on the seabed, because corals are a habitat for fish and marine plants; Prohibit the use of explosives and other chemicals in fishing and Prohibit the use of trawlers for fishing. Life on earth is a system of dependence between humans, animals, plants, and the natural surroundings. Breaking one of the links of the system will cause disruption of life. Therefore, the preservation of flora and fauna is an absolute concern for human survival.

Some responses have not yet demonstrated understanding and awareness of the business potential of environmental-based products and services. These conditions need to be given training and coaching in production activities, determining products / services, and measuring / indicator of potential products / services. Coaching activities begin with the provision of material environmental problems, environmental-based businesses, and production activities. Followed by other material. Some evidence of the implementation of activities as follows:

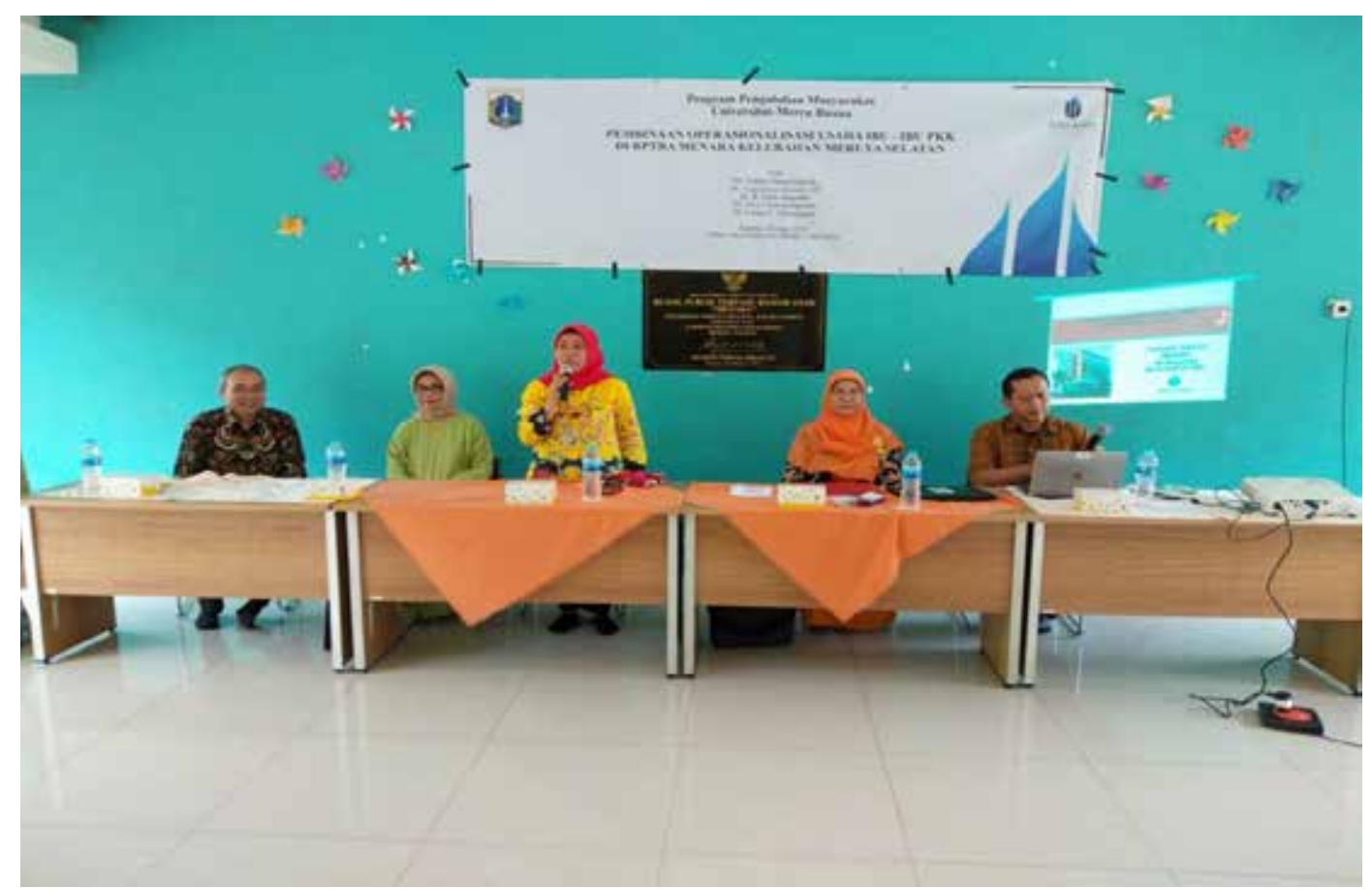

Figure 2: Submission of environmental-based product material and its development strategy 


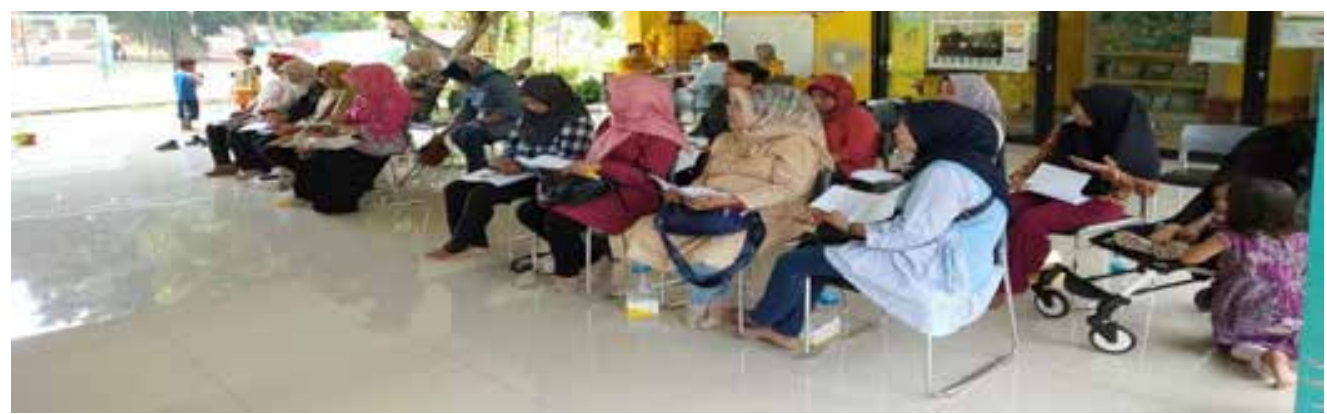

Figure 3. Activity Participants

ning and coaching activities by delivering material product activities and strategies based on the ronment, are expected to increase understanding and awareness of environmental issues and economic ntial. So PKK members and trainees in general need the importance of environmental preservation before ing products that are produced for consumers.

erstanding and awareness of environmental-based products can develop businesses that are sustainable. In ıctivity of delivering the material carried out interactively and passionately. PKK mothers and participants in ral have a high curiosity. The enthusiasm of participants that needs to be fostered continues to be committed sustainable.

people of South Meruya village have a lot of creativity in making ornamental flowers and processing palm $\mathrm{s}$, this activity is carried out when there is a will on the sidelines of other activities or when receiving orders. 1 the presentation that entrepreneurship is very much needed sustainability, as well as the strategy of uction activities, give enthusiasm to the people in South Meruya.

srative flower production activities require adequate and sustainable preparation of raw materials. In order to rge the business needed cooperation and coordination with similar entrepreneurs, also the ability to market. is activity also provided exposure to marketing efforts through print and electronic / social media, as well as therness with the PKK

vation and creativity in making crafts have been many and continue to increase. This condition still requires hing to continue to be committed and sustainable and needs to be reminded about the mindset of an spreneur including increasing turnover and developing.

\section{CONCLUSION}

1. Participants understand the environmental issues facing all humans so that everyone needs to be involved. Participation can be realized in the creation of activities that reduce pollution generation and save natural resources. The activity has economic opportunities that are suitable to the conditions of the community and the trainees

2. Participants understand the production / operational activities of businesses in building business sustainability as an important element of SMEs entrepreneurship. The most important elements in building competency and sustainability of environmental-based products: the mindset as an entrepreneur, the importance of sustainability of raw materials and sales, and the sustainability of production.

3. Participants understand the role of commitment as an important element in entrepreneurship sustainability in SMEs. The most important elements in building a commitment to business sustainability are: Willing to change your mindset into an entrepreneur; Willing to work hard and develop entrepreneurial values, Involve themselves consistently in the efforts of SMEs. 


\section{REFERENCES}

Alma Buchari; Kewirausahaan, Edisi Reviai. Bandung : Alfabeta, 2006.

Curtis, Susan; and Dennis Wright. Retaining Employes- The Fast Track to Commitment, Management Reserach News, Volume 24.

Gibson, James L.; Ivancevich, Jhon M.; Donelly, James H.;Konopaske, Rober. Organization,

Bahavior, Structure, Process, Edisi $13^{\text {th }}$ ed. Boston : McGraw-Hill (2009)

Jay Heizer \& Barry Rnder; 2009. Manajemen Operasi. Edisi 9. Jakarta. Salemba 4

Hjelle, Larry A. \& Daniel J. Ziegler (ed). Personality Theories. New York : McGraw-Hill Inc., 1992.

http://enterpreuneurship.blogspot.co.id/2011/12/karakter-seorang-wirausaha-pada.html

Shermon ,Ganesh. Competrency Based HRM, A Strategic Resource for Competency Mapping Assessment and Development Centres, New delhi :Tata McGraw Hill Education Private Limited, 2004

Santosa, Singgih. Buku Latihan SPSS, Statistik Parametrik. Jakarta : PT. Elex Media Komputindo, 2000.

Sopiah. Perilaku Organisasi.Yogtyakarta : Andi. 2008.

Sugijono. Metode Penelitian pendidikan Bandung: Alfabeta, 2008.

Suparman, M. Atwi, Desain Instruksional Modern. Jakarta : Erlangga, 2002.

Uno , Hamzah B., Masri Kudrat Umar, Kaysar Panjaitan. Variabel Penelitian Dalam Pendidikan Dan Pembelajaran. Jakarta : PT Ini Publikatama, 2014.

Woolfolk, Anita E. Educational Psychology. Boston,: Allyn \& Bacon, 1993 